\title{
LINKING ENTREPRENEURIAL ORIENTATION AND INNOVATION INTENSITY: MODERATING ROLE OF ENVIRONMENTAL TURBULENCE
}

\section{Syed Shahan Ali Zaidi ${ }^{1}$ and Syed Shahid Zaheer Zaidi ${ }^{2}$}

\begin{abstract}
This research aims to investigate the impact of entrepreneurial orientation dimensions on a firm's innovation intensity along with the moderation of environmental turbulence. The dimensions of entrepreneurial orientation include autonomy, pro-activeness, risk attitude, innovation readiness and competitive aggressiveness, hence the study includes five direct hypotheses and five moderated hypotheses. The data was gathered through an online questionnaire. The sample size of the study was 386 small and medium enterprises (SME) operating in Pakistan. The questionnaire was filled out by executive managers or executive directors of organizations as company representatives. Smart PLS was used to analyze the data. The measurement model was run to ensure validity and reliability. Moreover, the outer loadings, model fit and important statistics were assured. The structural model estimated the proposed relationships of the study. The findings of the study suggested a positive impact of all the dimensions of entrepreneurial orientation on innovation while the moderation effect of environmental turbulence was found to be significant for all the relationships except innovation readiness. The study finally concluded that EO had a significant impact on innovation intensity. Based on the findings, it is recommended that SMEs should enhance entrepreneurial orientation in their respective organizations in order to intensify innovation. The practical objective of this research was to gain knowledge on entrepreneurial orientation and innovation intensity that is crucial for organizations in the contemporary business world. The study has certain implications for the development of organizations' strategic orientation. SMEs in Pakistan have great potential and in terms of intensifying innovation in enterprises, it is important to focus on entrepreneurial orientation. Thus, SMEs have to be innovative, proactive, and ready to take risks which may ultimately help them improve their performance.
\end{abstract}

Keywords: Entrepreneurial Orientation; Innovation Intensity; Environmental Turbulence; Small and Medium Enterprises; Innovation Readiness; Strategic Orientation.

\footnotetext{
${ }^{1}$ Department of Public Administration, University of Karachi, Pakistan. Email: ss.alizaidi1105@gmail.com

${ }^{2}$ Department of Public Administration, University of Karachi, Pakistan. Email: sszzaidi@uok.edu.pk
} 


\section{INTRODUCTION}

For a long time, innovation has occurred through the path of entrepreneurial orientation (Dalton \& Logan, 2020; Okonkwo, 2020). It has been claimed by researchers that the concept of entrepreneurial orientation is the most highlighted and acceptable paradigm that exists in the literature for corporate entrepreneurship (Jones \& Colwill, 2013). Entrepreneurial orientation (EO) is usually defined as the tendency of behavioural aspect and help to empower the firms' framework to become more innovative (Hosseini et al., 2017). The construct of EO was first introduced by Miller (1983) which encompasses three elements i.e., risk-taking, innovation, and pro-activeness (Miller, 2011).

On the other hand, innovation is a wider concept and cannot be explained by one definition rather it has been categorized into different classes and types like innovation process, innovation technology, innovative markets and product innovation, having different scales to measure them from incremental to essential innovation. The researchers have further linked innovation to stimuli resolution contrivances and responses (Bouguerra et al., 2020; Pihlajamaa, 2017), this attempt also aids to enhance the knowledge and build new models subsequently (Lawal, 2020; Kocak et al., 2017). Literature does not enlighten the concept if either innovation in entrepreneurial orientation is an output or input element (Baregheh et al., 2009). Prior studies underline the fact the innovation is not an isolated occurrence either it is considered as a process that involves both factors of input and output (Forsman, 2011; Vasconcellos \& Marx, 2011; Sebora, \& Theerapatvong, 2010).

With the pace of time globalization has become pervasive, and different corporate sectors are experiencing a higher growth rate, resulting in a more healthy competition that helps the economy to grow. All these factors thus instigate the need for entrepreneurial orientation in the business sector. Moreover, in Pakistan, even public limited companies are closely held and run by wellknown entrepreneur families (Arif \& Syed, 2015). These sectors are more willing to attract investors from foreign countries and sanction their entrepreneurs. The ultimate objective vested in enhancing the corporate sector is to eliminate unemployment, especially in youth. Having a suitable entrepreneurial approach in the corporate sector is difficult since it does not have reliable measures and proper corporate culture. Innovation is important for organizations to survive and prosper. Ahmed and Shepherd (2010) stated that innovation is important because it helps to explore areas for improvement, it also highlights the firms' strength, it allows the organizations to evaluate 
their performance, it also helps to figure out the reasons for poor implementation and also helps identify new opportunities. Several researchers suggested that the process of innovation is the compression of input and output aspects (Forsman, 2011; Vasconcellos \& Marx, 2011; Teixeira, 2010). Thus, EO has significance but does not ensure output especially related to innovation in generating new services, goods, methods of production, and new workplace or market.

Therefore, innovation within the EO framework must be discussed in the literature. Additionally, the EO framework doesn't describe in detail the aspect of the innovation dimensions. It does not mention the level of innovation in terms of radical innovation and incremental innovation. It does not explain the types of innovation such as administrative, process, product, and technical innovation (Subramaniam \& Youndt, 2005; Garcia \& Calantone, 2002; Damanpour \& Schneider, 2006). Hence there is a need to study the relationship of EO with innovation intensity.

\section{LITERATURE REVIEW}

\section{Innovation Intensity}

Previously a study by Walter et al. (2006) was conducted to clarify the concept of innovation with the framework of EO. Walter et al. (2006) describe the innovation within the EO framework as a tendency to support creativity, new ideas, experimentation, and novelty which also challenge the present technologies, norms, and practices of the organizations which leads to new processes and products. The definition by the Walter et al. (2006) to explain innovation within the EO framework shows that the objective is to compute the innovation readiness in which they did not pay attention to the outcome or Schumpeterian innovation, which is known as the creative destruction by introducing new services and product that can change the dynamics of the market (Schumpeter \& Nichol, 1934). Additionally, the definition of innovation intensity proposed by Walter et al. (2006) is similar to the definition of Tonnessen's (2005) who call it 'generation of ideas' and Wang and Ahmed's (2004) who claim its relation to 'behaviour and processes'. It has been concluded that innovative input or readiness to innovate (the environment for innovation) will help to achieve an innovative outcome. We can say that organizational innovation is linked with readiness to innovate, the process involves the capability to enhance innovation with the help of a strategic approach for the innovative attitude held by organizational leadership, culture, and structure (Bastic \& Leskovar-Spacapan, 2006). Further, developing the capabilities and capacity of 
innovation based on the resource-based view is also suggested by Atuahene-Gima (2005) and Hurley and Hult (1998).

Research by Deloitte (2004) has pointed out that there were literature gaps related to organizational intention to adopt innovation and assessing their capabilities to implement innovation. This statement was also proposed by Nagji and Tuff (2012) who argued that regardless of intention, organizational innovation failed due to the lack of organizational capabilities. Another researcher elaborates that learning and knowledge are the main resources and act as a source of innovation Tidd (2005). The capabilities depend on the acquired process of knowledge and its management. According to Merx-Chermin and Nijhof (2005), to gain knowledge and capabilities, an organization must convert into a learning organization. Learning can assist an individual or organization to share knowledge and maintain trust. As per Sumo et al (2014) incremental innovations can be driven by employee-based activities like a collaboration of ideas and radical innovations can be achieved by development based competence.

In general, EO is considered to be a driving force for the innovation capabilities of a firm. Despite having a clear image of innovation capabilities and their impact on the firm performance, scant literature is available that discusses the EO dimension and its positive impact on the innovation output of the organization (Wang et al., 2015). Similarly, Kanter (2010) highlighted the importance of competencies to gain innovation. The dimension of innovation within the EO framework is 'ready to innovate' proposed by Dess and Lumpkin (2005) and Rauch et al. (2009) who claim that innovation is linked to the willingness to involve in experimentation, creativity, and massive efforts.

Researchers also underline the point that innovation is a process that helps to build capacity to embrace the new product, service, or process (Marion \& Fixson, 2020). Literature shows various studies that discussed the relationship between innovation and EO. The research by Indriastuti, (2019) asserts that the employees' innovativeness is considered as their self-ability to adopt creativity and face challenges to improve their work, product, and procedural performance. Excessive involvement of administration and bureaucracy mishandles the process of innovation. It results in traditionalism, learning deficiency, and unwillingness to support innovation (Kuzminski et al., 2020). Therefore, to achieve innovation, management must have managers who promote innovative ideas and experiments. Similar to this point, Shanker et al. (2017) also 
concluded a positive relationship between innovation and organizational climate. Hughes et al. (2020) found that research must be conducted on the information relating to the advantage of opportunity-seeking via innovation. The literature also clarifies that innovation is not only an internal driven force but it can be achieved from outside of the firm that improves the ability and capability of a firm to be innovative (Khan, 2021). According to Marvel et al. (2020), the venture units are helpful to bring innovation in the firms and to introduce new services and products as they are comparatively free from the constraints of inter-organizational boundaries.

Additionally, Yi et al. (2021) found that investment practices are undertaken by entrepreneurial firms through private ventures that help in building innovative start-ups. These private ventures assist organizations to enhance their processes through new technology adoption which also allow organizations to bring innovation. Gaba and Bhattacharya (2012) further added that ventures in an organization help in progressive research and technology through external collaborations.

\section{Entrepreneurial Orientation}

EO (Entrepreneurial Orientation) can be described as a process of entrepreneurial activity at the organizational level. Strategic management can be identical to the EO. According to Miller (2011) firms that follow entrepreneurial activity involve in innovative product development, are responsible for risky ventures, are usually the first movers, follow a proactive approach and earn a competitive advantage. In short, we can say that Miller (2011) has defined EO as a concept that comprehends risk-taking, innovation readiness, and proactiveness. However, massive information on EO is available in the literature but the definition proposed by Miller (2011) is considered as an original concept of EO because it has argued about the inherent nature of the EO construct (Covin \& Wales, 2012).

EO is an important concept while conversing firm performance, entrepreneurial orientation is a vital factor that helps an organization to discover new opportunities in the market (Chang, 2017; Caseiro \& Coelho, 2019). In the current study, we have distinguished five dimensions of EO as proposed by Miller (2011) and Dess and Lumpkin (2005) namely, innovation readiness, proactiveness, risk-taking, autonomy, and competitive aggressiveness. It is proposed that a firm that practices EO is more likely to discover new opportunities in the market (Gawke et al, 2019; Adomako et al., 2021), and they can also manage new challenges such as uncertain environment and competition (Clausen, 2019). 
Prior studies have concluded that entrepreneurial orientation dimensions can help to achieve growth in the market (Adomako et al., 2021) and the performance of an organization (Hossain \& Asheq, 2020). The innovative readiness dimension of EO reflects the level of involvement and ability to support creativity such as introducing new services, products, or technologies. Innovative firms usually have a large number of knowledgeable and skilled employees that lead to establishing unique competencies (Sanyal et al., 2020).

Literature shows that strategic decision making develops with a distinctive process of organizational steps (Hashem, 2018). The process includes different modes and patterns that can be categorized and identified (Hashem, 2018). Karadağ \& Şahin (2020), presented the concept of entrepreneurial management by analyzing the methods, processes, and styles that firms follow to behave entrepreneurially, which is similar to the concept of entrepreneurial orientation. While investigating EO dimensions Miller (1983) provided a comprehensive model. As mentioned above, he used three-dimension to confers EO i.e., proactiveness, risk-taking, and innovative readiness.

Many researchers conducted their study based on the original concept of EO proposed by Miller (1983) (e.g., Chen et al., 2015; Kottika et al., 2020). For example, a study was conducted in an EO firm to test the performance in a non-threatening and hostile environment by Covin and Wales (2012) using a sample of 161 small level manufacturers, the results show that the firms consider entrepreneurship if they follow the phenomenon of proactiveness, risk-taking, and innovation readiness. Moreover, two other dimensions are very important to analyze EO. First, competitive aggressiveness, which Miller (1983) describes in the definition of an entrepreneurial organization as the idea of competing with the rivals. We can explain competitive aggressiveness as the intensity of the competition in most cases where a new entrant in a market has to compete head-to-head with already existing competitors. The correlation of competitive aggressiveness is high with entrepreneurship through all risk levels as observed in published studies talk about different risk levels of the firm i.e. high and low-risk environments (Dean, Thibodeaux, Beyerlein, Ebrahimi, \& Molina, 1993).

Another key component is autonomy, it refers to the level of independence and autonomous action. New businesses must practice intentionality to perform required actions in order to introduce novel ventures (Badoiu et al., 2020; Hoyte et al., 2019). Layers of regulation and traditions of firms 
hardly contribute to the new venture activity (Zhao et al., 2020). As an alternative, it requires a strong individual that possesses autonomy or creative personnel who are not directly engaged with the new entry constraints of a firm. According to Hettich \& Kreutzer (2021), in the area of cooperative venturing, the autonomy of individuals in the operational capacity act as the motor of corporate entrepreneurship.

The construct of Entrepreneurial Orientation has to earn imperious attention in the empirical literature of entrepreneurship. Entrepreneurial Orientation has been defined by Lumpkin and Dess (1996) as the involvement of key players and their actions and attention in a dynamic process of reproduction that creates a new venture. They further added that it is an organizational process, style, and method that a firm decides to perform as an entrepreneur. The current study has adopted the definition of EO presented by Lumpkin and Dess (1996).

A detailed analysis of both definitions reveals that EO is considered to be a tendency of a behavioural characteristic and it works as input that measures the impact on firm performance. According to the researchers, EO refers to behavioural susceptibility which demonstrates itself as a tendency and willingness to involve in entrepreneurial activities (Covin \& Wales, 2012; Hosseini et al., 2012). Covin and Wales (2018) also found that EO involves firm-level practices, processes, and helps in decision making and recruits the behaviour of an entrepreneur. In other words, we can say that EO facilitates and designs the conditions of the firm that promote the activities of EO and help to gain entrepreneurial outcomes. Earlier, Stevenson and Jarillo (1990) also supposed this viewpoint by emphasizing that $\mathrm{EO}$ is rooted in the strategic level philosophy of the organization, which molds the behaviour and helps in decision making for better services and goods, new markets, and different methods of production.

However, the dimensions of EO mostly demonstrate a strategic process and it deals with a behavioural propensity, and the factors of EO treat themselves as input features. Another researcher conducted a meta-analysis and claims that 134 researchers have declared EO factors as a determinant of input and they influence the performance of the firm (Rauch et al., 2009). On the contrary, some researchers focus on the firm's performance and EO with a moderating role of organizational factors. The researcher also underlines the fact that 67 studies have used EO as an input factor and investigated its impact on organizational performance (Miller, 2011). Therefore, EO can help with outcomes especially in innovation and helps in decision making for better 
services and goods, new markets, and different methods of production. Dess and Lumpkin (2005) investigated and found that five factors i.e., risk-taking, autonomy, innovation, competitive aggressiveness, and pro-activeness simplify new entry.

Covin and Slevin (2012) argued that there are three factors of EO i.e., pro-activeness, risk-taking, and innovation. According to Covin and Slevin (1991), EO can be described as the level to which upper managers are willing to take risks related to business (dimension of risk-taking), to avail changes and create innovation in order to achieve a competitive advantage (dimension of innovation) and to compete with other organizations (dimension of pro-activeness). It can be seen from the previous statement that the pro-active dimension was assorted with competitive aggressiveness.

Furthermore, Lumpkin and Dess (1996) added another two-dimension in the construct of EO namely autonomy and competitive aggressiveness. Later, Lumpkin and Dess (1996) developed the definition of pro-activeness as the perspective of looking forward and seeking the opportunity that involves new services and products that help organizations to become better than the competitors and analyze the future demand of the organizational environment.

Additionally, Dess and Lumpkin (2005) notified that EO is the centre of explaining and understanding entrepreneurship, but it does not encounter all the aspects of entrepreneurship. To conclude we can state that there are five dimensions namely innovative readiness, risk-taking, autonomy, proactiveness, and competitive aggressiveness, the subsection of these five dimensions is studied further. Although the current study focuses on these five dimensions as a leading part of EO our discussion may vary as we argued these dimensions independently in a given circumstance. The figure below presents the research model of the study. 
Figure 1. Research Model

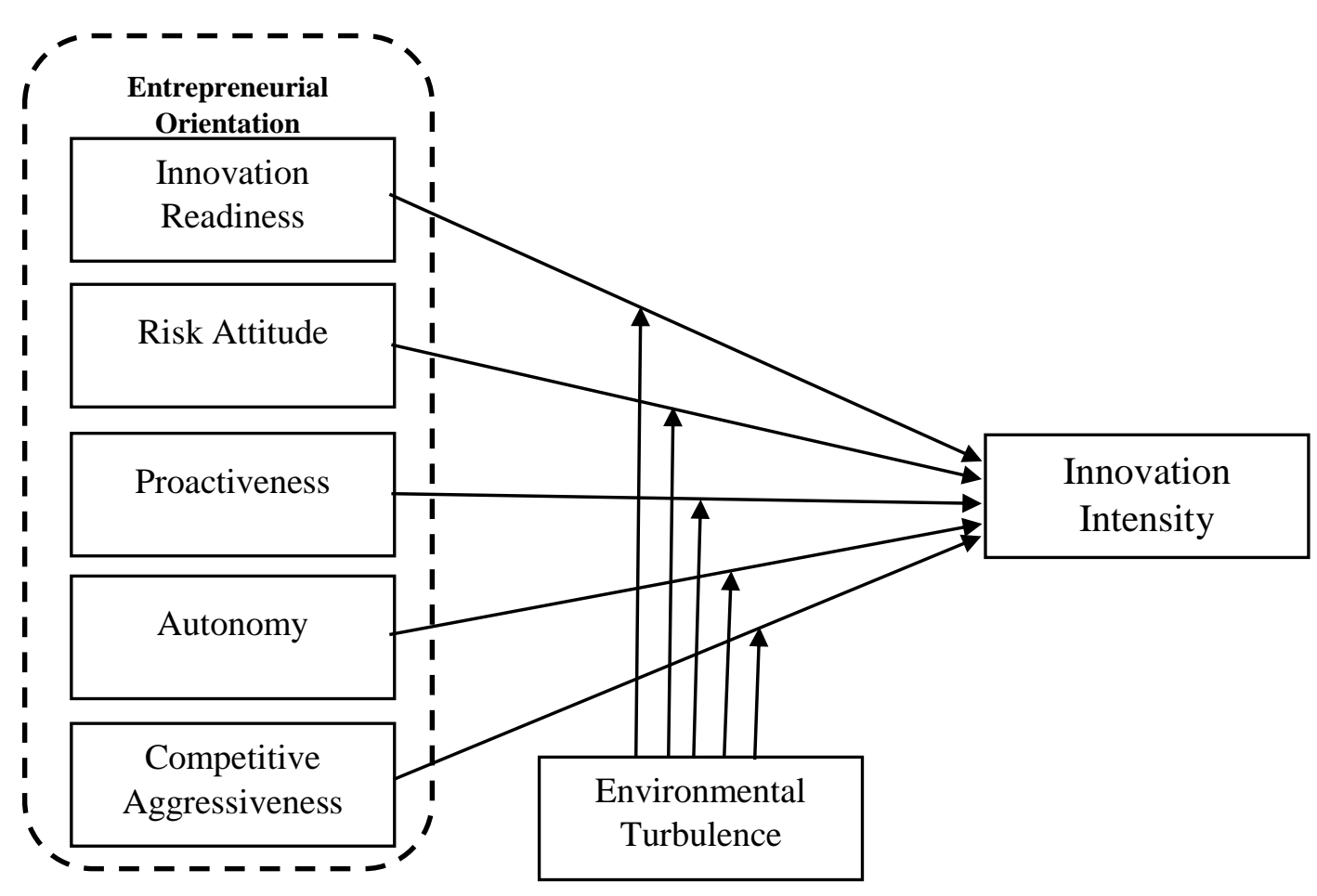

Source: Study Analysis

\section{HYPOTHESES DEVELOPMENT}

\section{Entrepreneurial Orientation and Innovation Intensity}

Innovation is believed as a process that involves assets, and on the other hand, EO facilitates the organization to select and combine the resources that can lead to innovation (Arif \& Aziz, 2018). Even though it is an important area to explore, there is a lack of research in this field, and the original variable is also a new entry into the study. A study conducted by Benazzouz (2019) investigated the strategic orientation impact such as technology orientation, market orientation, and entrepreneurial orientation through innovation and then with a performance of a firm. According to the results, EO has a positive impact on market innovation and technology innovation. Some researchers have focused on the narrow relationship between innovation and $\mathrm{EO}$, thus the first main hypothesis for the current study is stated as:

H1: Entrepreneurial Orientation has a significant positive impact on the innovation intensity of the firms. 


\section{Innovation Readiness and Innovation Intensity}

As discussed above innovation is the willingness to create something new (Rondi et al., 2019). There is a difference between innovation readiness and innovation. Innovation is related to the development of a new product, service, or even a process different from the present. Whereas innovation readiness or innovativeness is considered as the tendency to innovate. Business and innovation resources play important role in firm performance (Aziz \& Arif, 2020). It is known as the will of the organization to produce new or innovative, but it does not consider the result such as service, product, or process. Innovation readiness can be subjected to the cause-effect model. According to Randerson and Fayolle (2010), previous researchers show the relationship between EO with different variables but analyzing the relationship between innovation readiness and innovation intensity is rare. Recent studies contribute to this area by showing that the motivation of individual management is considered as a significant factor of innovation (Pihlajamaa, 2017). The innovation readiness is an EO dimension and still, the concept is under developing stage. Best to our knowledge, this research part put all the primers of new products or services under the same grip, without considering the source of knowledge either from knowledge adoption presented by other firms or generation of new knowledge internally. In other words, previous researches do not provide the difference between a firm's tendency to be innovative in form of new products in an organization or new to the world as an innovative product.

An organization that labels itself with entrepreneurial orientation usually depends on the skill and internal knowledge of its employees and treats them as input in the process of knowledge gathering (Lumpkin \& Dess, 1996). From the above discussion we developed the following hypothesis:

H1a: Innovation Readiness has a significant positive impact on the Innovation Intensity of the firms.

\section{Risk Attitude and Innovation Intensity}

Based on the literature that discussed the relationship of II and EO, most of the researches shows a positive and significant relationship between both the constructs in various firms and industries. Researchers also claim that proactiveness and risk-taking attitude are the two key dimensions of EO that shows the relationship with innovation and also enhances the firm's performance (Utami et al., 2021). These results are also supported by other researchers as well, i.e., risk-taking attitude 
shows a positive impact on the process of innovation and thus upper-level management supports new ideas and also allocates huge resources in the implementation of these ideas (García-Piqueres et al., 2019).

Additionally, the EO construct is highly correlated with internationalization, which is considered as a good innovation intensity indicator ( $\mathrm{Yu} \& \mathrm{Si}, 2012)$. EO also helps to increase the frequency of innovation (Gupta et al., 2012). As per Brion and Mothe (2017), there are factors that affect risk-taking attitude and favor innovation in an organization, depending upon creative and new ideas, despite higher chances of failing with their innovation. Another study was conducted in the context of SMEs by Mazzarol and Reboud (2004) emphasize the significance of risk evaluation and its relationship with innovation. If an organization analyzes their risk, it will help them to make appropriate strategies that lead to imitation or replacement of innovation, which shows the connection between a risk-taking attitude and innovation intensity. Moreover, these two dimensions of EO i.e., risk-taking and proactiveness are not only associated with the Innovation intensity but both constructs have a different link with innovation nature that firms follow such as generation or adoption. From the above discussion we generated the following hypothesis:

H1b: Risk Attitude has a significant positive impact on the Innovation Intensity of the firms.

\section{Pro-activeness and Innovation Intensity}

The EO dimension 'proactiveness' suggests how a firm can distribute, define, and responds to the given information (Le Loarne-Lemaire \& Blanco, 2012). With the help of entrepreneurial orientation, an organization can investigate its organizational capital via various initiatives of entrepreneurial activity. EO also promotes the entrepreneurial culture which usually exists with the team of entrepreneurial coordinators that support innovation ingenuity (Ribeiro-Soriano et al. 2019). It has been observed from the past studies available on innovation with the EO dimensions, most of the researchers consider innovation as a whole and refer to it as a creation of a new product, service, or process in the marketplace irrespective of it being either a generation of innovation or adoption of innovation.

Thus, the current study depends on the literature and generate the hypothesis to assume that proactiveness predicts innovation in both generation and adoption manners. Based on the basic definition of Proactiveness 'willingness to act and make a competitor to response' it shows that 
proactivity has a significant impact on the innovation process (Covin \& Wales, 2012). From the above discussion following hypotheses is developed:

H1c: Proactiveness has a significant positive impact on the Innovation Intensity of the firms.

\section{Autonomy and Innovation Intensity}

Autonomy in the context of entrepreneurial orientation dimension is that the authority possessed by the team, or an individual performs their given task (Lumpkin \& Dess, 1996). Previous researches has found a positive impact of autonomy on innovation, it also increases firm effectiveness and earns competitive advantages, along with the support of a new venture (Houck et al. 2003). Innovation is a key factor in an organization to keep the firm stable due to the everchanging market environment (Bueno et al. 2004). Innovation has a direct impact on the performance of a firm (Hu et al. 2020).

According to Ireland and Webb (2006), the innovation process is directly affected by entrepreneurial actions. So, we can say that entrepreneurial orientation (EO) increases competitive aggressiveness, autonomy and proactiveness, risk-taking and innovation readiness, it also links to innovation intensity and firm performance (Zahra et al., 2001; Lumpkin and Dess, 1996). Even though, prior researchers have found that innovation work as an indicator of EO and entrepreneurship, however, only a few empirical studies are available that discussed their relationship. Scholars also emphasize the fact that to attain EO autonomy at a higher-level strategic involvement is important (Lumpkin, et al. 2009). Researchers have further stated that the expected outcome for the individual or organization can be achieved by providing autonomy to the individual or player of a firm. Above all the autonomy process must follow as per the policy of the organization and backing organizational objectives. From the above discussion we developed the following hypothesis:

H1d: Autonomy has a significant positive impact on the Innovation Intensity of the firms.

\section{Competitive Aggressiveness and Innovation Intensity}

Gupta \& Dutta (2018) highlighted that competitive aggressiveness is a situation where an organization wants to perform better than everybody in a market. Competitive aggression can be occurred in two ways i.e., responsive, and reactive. Reactive competitive aggressiveness behavior 
can be observed when an organization directly reacts to the competitors' action for example an organization using price cut method to retain their customer in a market that can be dismissed due to the new technology or product presented by the competitor. Whereas responsive competitive aggressiveness behavior is when an organization is involved in head-to-head competition.

Basdeo et al. (2006) underline the fact that competitive aggressiveness and innovation has evidence of connections, they found that development of a new process, service or product, and innovation is considered as an example of competitive aggressiveness and also causes troublesome competition such as price cuts. Hence the innovation dimension influences on the competitive aggressiveness dimension. Another researcher who shows the relationship between competitive aggressiveness and innovation stated that different levels of innovation are showing innovation at different levels Blackford (2014). He further stated that the senior authorities of an organization must admire innovation so that they can demonstrate the organization aggressively as well as the ability of the firm to stay motivated and aware of the current market, and also assist than to act aggressively (Chen et al., 2015; Yu \& Cannella, 2007). From the above discussion we generated the following hypothesis:

H1e: Competitive Aggressiveness Readiness has a significant positive impact on the Innovation Intensity of the firms.

\section{Moderation by Environmental Turbulence}

Instability and advancement in technology make products outdated very quickly, and thus the demand for new product ideas have helped to develop up to date products (Zhang et al. 2016). Researchers also pay attention to the organization lock-in environment. Bagheri (2017) stated that the crises in the marketplace are due to the interaction of researchers and firm, and weakness in the SMEs and enhancement in the flexibility and turnover of workers. Buisson and Silberzahn (2005) investigated the moderating effect of the environment and its impact on innovation. This approach is based on the environmental developing factors. The most attractive part was the discussion on the revolutions in market in the near future. The result shows that every product must enhance their technology and decrease service and product need.

The responsibility for expertise becomes paramount in the selection of distinctive breaks for the company. New ideas will serve as a basis for the implementation process. Radical changes in the industry or the competition intensity will have an influence on the business conduct in an 
organization. In this way, the environment will influence the relational capital and innovation intensity link. The company can rely on its customers to take advantage of new-product opportunities, offered by technological change (Sheng et al., 2016).

Due to the changing environment and technological dynamics, it allows the organization to trust their suppliers. With the help of this alliance development of a new products can become easier by using advanced technology. It also promotes the method of testing or trial and balance to achieve the most appropriate product based on technology thus improve resources (Wu et al., 2016). The influence of the environment on the innovation or capital of an organization is established based on organizational structures. Similarly, Burns and Stalker (1961) proposed two types of organizational structures i.e., dynamic adapted (environmental dynamics) and structures adapted (environmental stabilization).

Researchers also emphasize that the culture of an organization plays a significant role to deal with turbulence in the environment. As per Berthod et al. (2017), an organizational culture that is aware of the risk and vigilance, promotes learning on an ongoing basis. Inconsistent with this idea another researcher Bono et al. (2008) also underlines the need of having a culture that supports 'empowerment' and 'risk taking' rather than depending on wage culture. The environment turbulence also impacts the association between innovation and information system. Moreover, technological turbulence pushes firms to follow new information and communication system and develop new products or ventures. The advancement in technology also increases the knowledge pool along with innovation. Jones and Colwill (2013) claim that it helps an organization to practice innovation. Following the above discussion, we developed our hypothesis as:

H2: Environmental Turbulence moderates the significant positive impact of Entrepreneurial Orientation on Innovation Intensity of the firms

H2a: Environmental Turbulence moderates the significant positive impact of Innovation Readiness on Innovation Intensity of the firms.

H2b: Environmental Turbulence moderates the significant positive impact of Risk Attitude on Innovation Intensity of the firms.

H2c: Environmental Turbulence moderates the significant positive impact of Proactiveness on Innovation Intensity of the firms. 
H2d: Environmental Turbulence moderates the significant positive impact of Autonomy on Innovation Intensity of the firms.

H2e: Environmental Turbulence moderates the significant positive impact of Competitive Aggressiveness Readiness on Innovation Intensity of the firms.

\section{RESEARCH METHODOLOGY}

This section presents the unit of analysis of the study, data collection process, sample size, sampling technique and measures.

\section{Unit of Analysis, Data collection, Sample and Measures}

The unit of analysis regarding entrepreneurial orientation can be apprehended at both individual and organizational levels (Horchani \& Zouaoui, 2019). However, taking into account innovation most literature suggest the organizations to be the unit of analysis (Horchani \& Zouaoui, 2019). The one who responds to the questionnaire is the representative of the organization i.e., senior executive or executive director of the company. The selected companies in our sample are Pakistani SMEs.

For the present study a list of registered SMEs was obtained from SMEDA and using probabilistic technique of sampling i.e., simple random sampling 800 companies were selected and the questionnaires were distributed by e-mail, however only 15 responses were received. Facing such situation, it was decided to use non-probabilistic technique i.e., convenience sampling, allowing us to reach a good number of responses and the data was collected from more 380 companies. In total the collected data reached to 395 of which 9 questionnaires were discarded due to missing values of more than $20 \%$. Hence, the final sample reached to 386 . The sample characteristics are provided in the summarized table below.

Table 1. Demographic Analysis

\begin{tabular}{|c|c|}
\hline \multicolumn{1}{|c|}{ Criterion } & Percentage \\
\hline Company Age & \\
\hline$\bullet \quad$ Less than 5 years & 17.2 \\
\hline$\bullet \quad$ 5 to 10 years & 37.5 \\
\hline$\bullet \quad$ More than 10 years & 45.3 \\
\hline No of Employees & \\
\hline$\bullet \quad$ Less than 20 & 21.8 \\
\hline$\bullet \quad$ 20 to 250 & 57.9 \\
\hline$\bullet \quad$ More than 250 & 20.3 \\
\hline
\end{tabular}




\begin{tabular}{|c|c|}
\hline Activity sector & \\
\hline $\begin{array}{l}\text { - Manufacturing and/or manufacturing } \\
\text { related services }\end{array}$ & 42.0 \\
\hline $\begin{array}{ll}\text { - } & \text { Services and/or Information \& } \\
& \text { Communication Technology }\end{array}$ & 38.6 \\
\hline - $\quad$ Other & 19.4 \\
\hline
\end{tabular}

Source: Study Analysis

\section{Measures}

To measure entrepreneurial orientations, 29 items were used and the items for the sub-dimension are presented in the table below. The items were taken from Covin and Slevin (1989) mainly and to take the Pakistani context in account some of the items were also utilized from the work of Fayyaz and Shah (2017). Innovation intensity was measured by 7 items as utilized by Arshi (2016). The moderating variable of environmental turbulence was measured by 5 which were adopted from the study of de Waard et al. (2013). The instrument underwent multiple changes, and the final questionnaire was distributed for the data collection.

\section{DATA ANALYSIS AND DISCUSSION}

For filtering the measures, we used Exploratory Factor Analysis (EFA) using IBM SPSS version 22. The internal consistency of scales was tested by Cronbach's Alpha. In the case of present study, the reliability and validity of the questionnaire was verified by Confirmatory Factor Analysis (CFA) by Smart PLS 3. The study hypotheses were tested by using structural equation modelling (SEM) technique employing SPLS 3.

The use of SEM in management and administrative studies these days have great importance for the complex models with mediating and moderating variables (Khan et al., 2020). Wold (1977) introduced the PLS approach to SEM that ensures the model evaluation of the estimation by bootstrapping procedure. The items used for data analysis verified the validity and reliability. All items were scaled at point Likert from strongly disagree $=1$ to strongly agree $=5$ with a middle point $=3$. Table 2 below shows the factor loadings of each item included in a particular construct and table 3 presents the discriminant validity of each latent construct. 
Table 2. Factor Loadings of Items and Reliability of Constructs

\begin{tabular}{|c|c|c|c|}
\hline CONSTRUCTS & CRONBACH'S ALPHA & ITEMS & LOADING \\
\hline \multirow[t]{5}{*}{ AUTONOMY } & 0.83 & AUTO1 & 0.865 \\
\hline & & AUTO2 & 0.900 \\
\hline & & AUTO3 & 0.924 \\
\hline & & AUTO4 & 0.903 \\
\hline & & AUTO5 & 0.963 \\
\hline \multirow[t]{6}{*}{ COMPETITIVENESS } & 0.81 & COMP1 & 0.968 \\
\hline & & COMP2 & 0.895 \\
\hline & & COMP3 & 0.889 \\
\hline & & COMP4 & 0.926 \\
\hline & & COMP5 & 0.916 \\
\hline & & COMP6 & 0.934 \\
\hline \multirow[t]{7}{*}{ INNOVATON INTENSITY } & 0.75 & IR1 & 0.887 \\
\hline & & IR2 & 0.963 \\
\hline & & IR3 & 0.932 \\
\hline & & IR4 & 0.937 \\
\hline & & IR5 & 0.952 \\
\hline & & IR6 & 0.962 \\
\hline & & IR7 & 0.970 \\
\hline \multirow[t]{6}{*}{ PRO-ACTIVENESS } & 0.82 & PRO_ACT1 & 0.944 \\
\hline & & PRO_ACT2 & 0.937 \\
\hline & & PRO_ACT3 & 0.858 \\
\hline & & PRO_ACT4 & 0.915 \\
\hline & & PRO_ACT5 & 0.904 \\
\hline & & PRO_ACT6 & 0.942 \\
\hline \multirow[t]{5}{*}{ RISK ATTITUDE } & 0.79 & RA1 & 0.941 \\
\hline & & RA2 & 0.915 \\
\hline & & RA3 & 0.910 \\
\hline & & RA4 & 0.906 \\
\hline & & RA5 & 0.917 \\
\hline \multirow[t]{7}{*}{ INNOVATION READINESS } & 0.81 & INV_INT1 & 0.931 \\
\hline & & INV_INT2 & 0.896 \\
\hline & & INV_INT3 & 0.845 \\
\hline & & INV_INT4 & 0.897 \\
\hline & & INV_INT5 & 0.918 \\
\hline & & INV_INT6 & 0.922 \\
\hline & & INV_INT7 & 0.912 \\
\hline
\end{tabular}

Source: Study Analysis 
Table 3. Discriminant Validity of Latent Constructs

\begin{tabular}{|l|l|l|l|l|l|l|}
\hline & Autonomy & Competitiveness & $\begin{array}{l}\text { Innovation } \\
\text { readiness }\end{array}$ & $\begin{array}{l}\text { Innovation } \\
\text { intensity }\end{array}$ & $\begin{array}{l}\text { Pro- } \\
\text { activeness }\end{array}$ & $\begin{array}{l}\text { Risk } \\
\text { attitude }\end{array}$ \\
\hline Autonomy & $\mathbf{0 . 9 1 1}$ & & & & & \\
\hline Competitiveness & 0.376 & $\mathbf{0 . 9 2 2}$ & & & & \\
\hline Innovation readiness & 0.013 & 0.049 & $\mathbf{0 . 9 4 4}$ & & & \\
\hline Innovation intensity & 0.398 & 0.529 & 0.151 & $\mathbf{0 . 9 0 3}$ & & \\
\hline Pro-activeness & 0.128 & 0.181 & 0.093 & 0.271 & $\mathbf{0 . 9 1 7}$ & \\
\hline Risk attitude & 0.117 & 0.292 & 0.143 & 0.318 & 0.045 & $\mathbf{0 . 9 1 8}$ \\
\hline
\end{tabular}

Source: Study Analysis

The validation of the structural model was done in three states. In the first stage the focus was on quality of measurement model verified by average variance extracted (AVE), the second stage consisted of the quality of structural model which was verified by coefficient of determination $\left(R^{2}\right)$ of the model, and the third stage was to assess the quality of global model checked by goodness of fit ranging between 0 and 1 . The relationships presented in the conceptual model of the study were estimated by bootstrapping technique. The significance of the relationships were tested by the benchmark value of $t$ statistic of 1.96 and p-value less than 0.05 . The results of the structural model are summarized in the table 4 below. Moreover, the path coefficient and their significance has also been depicted in the bootstrapping model of PLS in the figure 2 below.

Table 4. Results of PLS Path Model Estimation

\begin{tabular}{|l|l|l|l|l|l|l|l|}
\hline Path & & & Estimates & T values & AVE & Alpha & $\begin{array}{l}\text { Composite } \\
\text { Reliability }\end{array}$ \\
\hline Innovation readiness & $\rightarrow$ & Innovation Intensity & 0.091 & $2.121^{*}$ & 0.89 & 0.81 & 0.90 \\
\hline Risk attitude & $\rightarrow$ & Innovation Intensity & 0.166 & $4.108^{* * *}$ & 0.81 & 0.79 & 0.88 \\
\hline Pro-activeness & $\rightarrow$ & Innovation Intensity & 0.161 & $3.604 * * *$ & 0.91 & 0.82 & 0.95 \\
\hline Autonomy & $\rightarrow$ & Innovation Intensity & 0.220 & $4.522^{* * *}$ & 0.83 & 0.83 & 0.91 \\
\hline Competitiveness & $\rightarrow$ & Innovation Intensity & 0.364 & $8.119 * * *$ & 0.85 & 0.81 & 0.95 \\
\hline
\end{tabular}

$R^{2} \quad=0.390 ;$ GOF $\quad=0.584$

Source: Study Analysis 
Figure 2. PLS Bootstrapping Model showing path coefficient with P-values

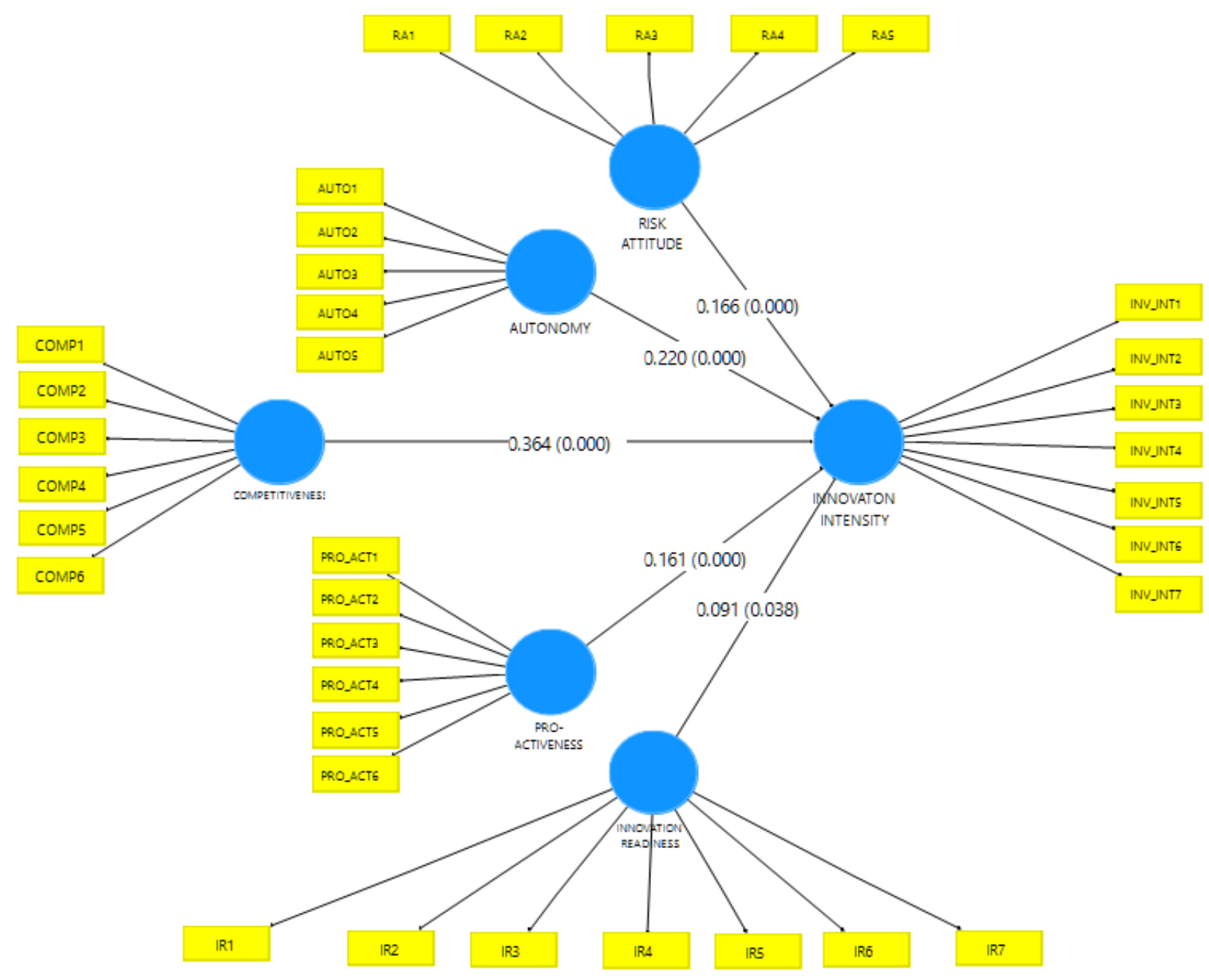

Source: Study Analysis

The hypothesis (H1a) of the study is related to the relationship of innovation readiness and innovation intensity. The above table of path coefficient assessment shows that the abovementioned hypothesis found to be positive and significant at 5\% level of significance. Innovativeness is a significant aspect but there is lacking prior researches to describe the importance of innovativeness based on Miller's (2011) perspective of innovativeness, which pays attention to the innovation activities of the product-market. Later, researchers also tried to analyze a different aspect of innovation readiness, for instance, Kreiser et al. (2019), enlighten the "technology policy", it is referring to the commitment of a firm to attain technology either deploying or developing technology. 
The hypothesis number $1 \mathrm{~b}$ of the study is related to the relationship of Risk Attitude and Innovation Intensity. The above table of path coefficient assessment shows that the above-mentioned hypothesis found to be positive and significant at $5 \%$ level of significance. Previous studies mainly focus on the difference between risky versus safe strategies. The differentiation among risk propensity, risk perceptions, and risk preferences. Another researcher argued that a higher level of EO enables a firm to take higher risks to attain a higher level of organizational performance (Hughes-Morgan et al., 2018). Furthermore, Hughes-Morgan et al. (2018) investigate the relationship between innovation and risk-taking, they concluded that a risk-taking attitude has a positive impact on innovation. Their main focus was on service and product innovation. They further added that innovation and risk-taking have a significant and positive impact on the organizational competitive advantage. Although, an innovation that includes risk is not always positive for example Radical innovation is sometimes riskier than incremental innovation.

The hypothesis number $1 \mathrm{c}$ of the study is related to the relationship of Proactiveness and Innovation Intensity. The above table of path coefficient assessment shows that the abovementioned hypothesis found to be positive and significant at 5\% level of significance. As stated by Lumpkin and Dess (1996), pro-activeness is a continuum where firms can act proactively or reactively as per their requirement. Chen et al. (2015) suggested that an organization should follow a proactive approach to bring innovation and respond to customers and technology. Likewise, Covin et al. (2012) also suggested that pro-activeness help develop new technologies, process, services, and product. Thus, the proactive is not only mixed up with competitive aggressiveness but also with a dimension of innovation.

Furthermore, Wang et al. (2021) also sustained this view and stated that pro-activeness and innovation work together, even innovation is based on pro-activeness. According to Nieto et al. (2013), an organization that focuses on innovation must change its operating ways as they penetrate a new market with a new product or service. They further concluded that both proactiveness and innovation have a significant impact on the performance of the firm.

The role of autonomy underlines in the discussion of the strategic process of activities related to entrepreneurship, however, both term is argued in two different contexts. Researchers explain the process of entrepreneurial strategy and observed that strong leaders always make appropriate and risky actions (Altamony \& Gharaibeh, 2017; Chaib Lababidi et al., 2020). The hypothesis number 
$1 \mathrm{~d}$ of the study is related to the relationship of Autonomy and Innovation Intensity. The above table of path coefficient assessment shows that the above-mentioned hypothesis found to be positive and significant at $5 \%$ level of significance.

The current study found that autonomy has a significant relationship with innovation intensity. Researchers also claim that the desire outcome of the organization can be achieved by providing autonomy to the players. Importantly, the autonomy must follow the rules and regulations decided by the organization and it must support the firm's goals and objectives. It is a comprehensive model that shows exploring new opportunities and decision-making occur in an organization at a lower level. The creative organization has been defined by Garvin and Levesque (2006) as an organization that possesses authority delegation and have flat hierarchies and operating decision making and support independent unit for a new venture. According to Burns et al. (2013), an organization that allows autonomy to their worker supporting an innovative environment. On contrary, Palmer et al. (2019), found that when autonomy is provided to middle managers, they have to create appropriate equilibrium between the breaking of rule resourcefulness. They further recommended that an organization must be capable enough to provide the best condition for the middle managers so that they can create an equilibrium position between organizational and personal initiatives. Another research stated that autonomy in the organization support innovation and creativity as well as connects it to employee traits (Zhang et al. 2016). Since autonomy is a positive feature for the organization but it has its abuses also as Shimizu (2012) found that autonomy promotes innovation in entrepreneurial, but it sometimes causes the unprincipled attitude of employees. He further added that in the new venture the effect of autonomy is difficult to evaluate as the venture is new in the marketplace. Zhang et al. (2020) claim that autonomy is linked with an attribute of an employee, and it is beneficial for an employee as it creates innovation. Subsequently, autonomy gives freedom, but it may have its abuses. Similarly, Shimizu (2012) argued that entrepreneurship is backed back autonomy, but it may lead to employee's devious behavior. He further added that in the generation of new ideas, the effort of autonomy cannot be measure properly as the idea is new and the market can behave in every way.

A study conducted by Covin and Wales (2012) investigate the extreme aggressive behavior of the firm to even attempt to eliminate the competitor from the market by setting objectives accordingly, or sometimes sacrifices the profit by cutting the cost harshly Stambaugh et al. (2020). The 
hypothesis number 1e of the study is related to the relationship of Competitive Aggressiveness and Innovation Intensity. The above table of path coefficient assessment shows that the abovementioned hypothesis found to be positive and significant at 5\% level of significance. The connection between competitive aggressiveness and innovation dimension has been observed by Basdeo et al. (2006), they concluded that development or innovation of the new product is a live example of a competitive move, if the firm cut their price, it considers as a disruptive competition. Thus, they link the dimension of innovation with competitive aggressiveness. Additionally, Blackford (2014) connected the dimension of competitive aggressiveness with the dimension of innovation by stated that innovation in different forms prevails in the market demonstrates innovation. He further added that the firm must have a strong attitude to react and higher authorizes must support innovation so the organization can become aggressively competitive. However, the researcher tried to clear the difference between innovation and competitive aggressiveness Stambaugh et al. (2020). They claim that the phenomenon to operate as both the factors are different as they involve different logics. The agenda of innovation is not always competitive aggressiveness but maybe an alternate product of it. The level of firm competitive aggressiveness can be measured by the motivation, awareness, and capabilities of a firm (Stambaugh et al., 2020).

\section{Hypothesis Testing for Moderation Analysis}

The current study proposed to check the moderating effect of audit committee in the relationship of the three independent variables (control environment, control activity, monitoring, information communication and risk assessment) on the dependent variable i.e., financial performance. For this purpose, three hypotheses were developed, and they were tested through PLS. The results of the moderation effects are shown in the following table 5.

Table 5. Moderation Effect of Audit Committee

\begin{tabular}{|l|l|l|l|}
\hline Relationship & $\begin{array}{l}\text { P-value without } \\
\text { Moderation }\end{array}$ & $\begin{array}{l}\text { P-value with } \\
\text { Moderation }\end{array}$ & Moderation \\
\hline Autonomy $\rightarrow$ Innovation Intensity & 0.000 & 0.045 & Yes \\
\hline Competitiveness $\rightarrow$ Innovation Intensity & 0.000 & 0.000 & Yes \\
\hline Innovation Readiness $\rightarrow$ Innovation Intensity & 0.034 & 0.952 & No \\
\hline Pro-Activeness $\rightarrow$ Innovation Intensity & 0.000 & 0.000 & Yes \\
\hline Risk Attitude $\rightarrow$ Innovation Intensity & 0.000 & 0.000 & Yes \\
\hline
\end{tabular}

Source: Study Analysis 
Regarding the analysis of moderation effect, the aforementioned table 5 shows that there is a significant moderating effect of environmental turbulence in the relationship between the independent variables; autonomy, risk attitude, competitiveness and pro-activeness and the dependent variable; innovation intensity. However, the results do not support the moderation effect of environmental turbulence in the relationship of innovation readiness and innovation intensity. In the analysis of PLS-SEM, the existence of a moderating effect is indicated when the value of interaction path is significant, meaning that $\mathrm{P}$ statistics of interaction effect must be less than 0.05 (Hair et al, 2015).

\section{CONCLUSION}

A comprehensive review of literature and the potential theories was carried out for the development of the research framework. The research framework provided in the previous section was influenced by earlier works done in the field of Entrepreneurial Orientation (EO) and Innovation Intensity (II). Based on the literature support and the theories the theoretical framework suggests that entrepreneurial orientations (EO) are an important predictor for the SMEs innovation intensity as suggested by the researchers and the theories. Research framework of this study explored the relationship of the EO and II. In addition, the research framework of the study also checks the moderating role of environmental Turbulence. The results were supportive and all entrepreneurial orientation dimensions positively affected innovation intensity. Furthermore, the moderating role of environmental turbulence was also found to be significant.

\section{STUDY IMPLICATIONS}

The main purpose of this research is to provide practical and valuable outcomes for the SMEs sector. The study findings indicated that entrepreneurial orientations (EO) dimensions significantly impact the innovation intensity of the firm and there is moderation in environmental turbulence on the relationship discussed above. All EO dimensions positively affected innovation intensity.

Moreover, the said relationships are confirmed from the practices as the data was collected from the top executives of the SMEs in Pakistan. The current study implies that SMEs in Pakistan if focus on each dimension of entrepreneurial orientation, then the intensity to innovate will increase. Hence the organizations that have better EOs tend to be more innovative. 
The results and findings of the current study have also important implications for strategic orientation development in organizations. The empirical results show the potential of SMEs in Pakistan - SMEs need to innovate, be proactive in their firm strategic action and be ready to take risks significantly, may affect the firm performance. The managerial implications for SMEs are that, the challenges for demonstrating and practicing high quality Entrepreneurial practice must be allied with the process of innovativeness and pro-activeness in the SMEs firm.

\section{RECOMMENDATIONS}

Based on the study findings, it is recommended that the owners/managers of SMEs must enhance their practices regarding entrepreneurial orientations (EO) as it affects the innovation intensity of the firm. In regard to risk attitude, it is recommended that owners consider risk as an opportunity to grow their business in the long run because risk taking attitude enable organizations to bring innovation and take proactive decisions. The study also recommended that owners and managers of SMEs focus on the different dimensions of EO. The study has suggested that firms must bring innovation in their products and services as organizational growth and survival depends on innovation. Innovation is considered the soul of the organization. Therefore, to get a sustainable competitive advantage in the marketplace, organizations need to seriously focus on innovation. Based on the results of the current research, it is recommended that proactive decisions and actions are the main driver of innovation intensity. It is also recommended that the owner or manager must be focused on entrepreneurial orientations in their firm, and leaders must demonstrate their ability to enhance their level of innovativeness, risk taking behavior and pro-active behavior to increase innovation intensity.

\section{Acknowledgement:}

I thank the anonymous referees for their useful suggestions. Moreover, I dedicate this work to my family and friends.

\section{Author(s) Contribution:}

The idea of this paper was initially suggested by Syed Shahan Ali Zaidi and later it was refined by Syed Shahid Zaheer Zaidi. The contents of the paper i.e., the Introduction, Literature Review, Data Collection and Analysis were transcribed by Syed Shahan Ali Zaidi and were then revised by Syed Shahid Zaheer Zaidi, who also guided the overall work under his expert supervision. 


\section{REFERENCES}

Adomako, S., Amankwah-Amoah, J., Danso, A., Danquah, J. K., Hussain, Z., \& Khan, Z. (2021). R\&D intensity, knowledge creation process and new product performance: The mediating role of international R\&D teams. Journal of Business Research, 128, 719-727. https://doi.org/10.1016/j.jbusres.2019.08.036

Ahmed, P., \& Shepherd, C. D. (2010). Innovation Management: Context, strategies, systems and processes. Pearson.

Altamony, H., \& Gharaibeh, A. (2017). The role of academic researcher to Mintzberg's managerial roles. International Journal of Business Management and Economic Research, 8(2), 920925.

Arif, K., \& Aziz, S. (2018). The Impact of an Innovative CEO on the Financial Performance of an Organization. Asia Proceedings of Social Sciences, 2(2), 123-127. https://doi.org/10.31580/apss.v2i2.391

Arif, K., \& Syed, N. (2015). Impact of corporate governance on performance of a firm: A comparison between commercial banks and financial services companies of Pakistan. European Journal of Business and Management, 7(10), 54-60.

Arshi, T. A. (2016). Entrepreneurial orientation and its impact on innovation intensity in the Omani corporate sector.

Atuahene-Gima, K. (2005). Resolving the capability-rigidity paradox in new product innovation. Journal of marketing, 69(4), 61-83.

Aziz, S., \& Arif, K. (2020). Is Pre-Eminence in Financial Performance to the Innovative Ideas of the CEO (An Evidence from PSX 100 Listed Companies). International Journal of Innovation, Creativity and Change, 11(12), 178-197.

Badoiu, G. A., Segarra-Ciprés, M., \& Escrig-Tena, A. B. (2020). Understanding employees' intrapreneurial behavior: a case study. Personnel Review, 49(8), 1677-1694. https://doi.org/10.1108/pr-04-2019-0201

Bagheri, A. (2017). The impact of entrepreneurial leadership on innovation work behavior and opportunity recognition in high-technology SMEs. The Journal of High Technology Management Research, 28(2), 159-166. 
Baregheh, A., Rowley, J., \& Sambrook, S. (2009). Towards a multidisciplinary definition of innovation. Management decision.

Basdeo, D. K., Smith, K. G., Grimm, C. M., Rindova, V. P., \& Derfus, P. J. (2006). The impact of market actions on firm reputation. Strategic Management Journal, 27(12), 1205-1219.

Bastic, M., \& Leskovar-Spacapan, G. (2006). What do transition organizations lack to be innovative?. Kybernetes.

Benazzouz, N. M. (2019). Entrepreneurial orientation and innovation intensity: A synthetic literature review. International Entrepreneurship Review, 5(2), 23-36. https://doi.org/10.15678/ier.2019.0502.02

Berthod, O., Grothe-Hammer, M., Müller-Seitz, G., Raab, J., \& Sydow, J. (2017). From highreliability organizations to high-reliability networks: the dynamics of network governance in the face of emergency. Journal of Public Administration Research and Theory, 27(2), 352-371.

Blackford, B. (2014). CEO Statements of Aggressiveness and the Competitive Aggressiveness of Firms: Is There a Relationship?. Journal of Behavioral and Applied Management, 15(3), 140.

Bouguerra, A., Mellahi, K., Glaister, K., Hughes, M., \& Tatoglu, E. (2020). Revisiting the Concept of Absorptive Capacity: The Moderating Effects of Market Sensing and Responsiveness. British Journal of Management. doi.org/10.1111/1467-8551.12398

Brion, S., \& Mothe, C. (2017). Le contexte organisationnel favorable à l'innovation ambidextre. Revue Française de Gestion, 43(264), 101-115. https://doi.org/10.3166/rfg.2017.00108

Bueno, E., Ordonez de Pablos, P., \& Salmador Sanchez, M. P. (2004). Towards an integrative model of business, knowledge and organisational learning processes. International Journal of Technology Management, 27(6-7), 562-574.

Buisson, B., \& Silberzahn, P. (2010). Blue ocean or fast-second innovation? A four-breakthrough model to explain successful market domination. International Journal of Innovation Management, 14(03), 359-378.

Burns, R. G., DeForest, J. L., Marxsen, J., Sinsabaugh, R. L., Stromberger, M. E., Wallenstein, M. D., Weintraub, M. N., \& Zoppini, A. (2013). Soil enzymes in a changing environment: Current knowledge and future directions. Soil Biology and Biochemistry, 58, 216-234. https://doi.org/10.1016/j.soilbio.2012.11.009 
Burns, T., \& Stalker, G. M. (1961). Mechanistic and organic systems. Classics of organizational theory, 209-214.

Caseiro, N., \& Coelho, A. (2019). The influence of Business Intelligence capacity, network learning and innovativeness on startups performance. Journal of Innovation \& Knowledge, 4(3), 139-145. https://doi.org/10.1016/j.jik.2018.03.009

Chaib Lababidi, H., Lababidi, R., Colak, M., \& Dayan, M. (2020). Contingency effects of firm structure and environmental uncertainty on strategic planning process and firm performance: Evidence from UAE enterprises. Strategic Change, 29(2), 241-252.

Chang, C. H. (2017). How to Enhance Green Service and Green Product Innovation Performance? The Roles of Inward and Outward Capabilities. Corporate Social Responsibility and Environmental Management, 25(4), 411-425. https://doi.org/10.1002/csr.1469

Chen, M. H., Chang, Y. Y., \& Chang, Y. C. (2015). Entrepreneurial Orientation, Social Networks, and Creative Performance: Middle Managers as Corporate Entrepreneurs. Creativity and Innovation Management, 24(3), 493-507. https://doi.org/10.1111/caim.12108

Clausen, T. H. (2019). Entrepreneurial thinking and action in opportunity development: A conceptual process model. International Small Business Journal: Researching Entrepreneurship, 38(1), 21-40. https://doi.org/10.1177/0266242619872883

Covin, J. G., \& Slevin, D. P. (1989). Strategic management of small firms in hostile and benign environments. Strategic management journal, 10(1), 75-87.

Covin, J. G., \& Slevin, D. P. (1991). A conceptual model of entrepreneurship as firm behavior. Entrepreneurship theory and practice, 16(1), 7-26.

Covin, J. G., \& Wales, W. J. (2012). The Measurement of Entrepreneurial Orientation. Entrepreneurship Theory and Practice, 36(4), 677-702. https://doi.org/10.1111/j.15406520.2010.00432.x

Covin, J. G., \& Wales, W. J. (2018). Crafting High-Impact Entrepreneurial Orientation Research: Some Suggested Guidelines. Entrepreneurship Theory and Practice, 43(1), 3-18. https://doi.org/10.1177/1042258718773181

Dalton, J. T., \& Logan, A. J. (2020). Teaching and learning Schumpeter: A dialogue between professor and student. The Review of Austrian Economics. Published. https://doi.org/10.1007/s11138-020-00514-9 
Damanpour, F., \& Schneider, M. (2006). Phases of the adoption of innovation in organizations: effects of environment, organization and top managers 1. British journal of Management, 17(3), 215-236.

de Waard, E., Volberda, H. W., \& Soeters, J. (2013). Engaging environmental turbulence: drivers of organizational flexibility in the armed forces. European Security, 22(4), 576-594.

Dean, C. C., Thibodeaux, M. S., Beyerlein, M., Ebrahimi, B., \& Molina, D. (1993). Corporate entrepreneurship and competitive aggressiveness: A comparison of US firms operating in Eastern Europe and the Commonwealth of Independent States with US firms in other high risk environments. Advances in International Comparative Management, 8, 31-54.

Deloitte Research (2004), Mastering Innovation: Exploiting Ideas for Profitable Growth, Research Report.

Dess, G. G., \& Lumpkin, G. T. (2005). The Role of Entrepreneurial Orientation in Stimulating Effective Corporate Entrepreneurship. Academy of Management Perspectives, 19(1), 147156. https://doi.org/10.5465/ame.2005.15841975

Forsman, H. (2011). Innovation capacity and innovation development in small enterprises. A comparison between the manufacturing and service sectors. Research policy, 40(5), 739750 .

Gaba, V., \& Bhattacharya, S. (2012). Aspirations, innovation, and corporate venture capital: A behavioral perspective. Strategic Entrepreneurship Journal, 6(2), 178-199. https://doi.org/10.1002/sej.1133

Garcia, R., \& Calantone, R. (2002). A critical look at technological innovation typology and innovativeness terminology: a literature review. Journal of Product Innovation Management: An international publication of the product development \& management association, 19(2), 110-132.

García-Piqueres, G., Serrano-Bedia, A. M., \& Pérez-Pérez, M. (2019). Knowledge Management Practices and Innovation Outcomes: The Moderating Role of Risk-Taking and Proactiveness. Administrative Sciences, 9(4), 75. https://doi.org/10.3390/admsci9040075

Garvin, D. A., \& Levesque, L. C. (2006). Meeting the challenge of corporate entrepreneurship. Harvard business review, 84(10), 102.

Gawke, J. C., Gorgievski, M. J., \& Bakker, A. B. (2019). Measuring intrapreneurship at the individual level: Development and validation of the Employee Intrapreneurship Scale 


$\begin{array}{lcrrr}\text { (EIS). European } & \text { Management } & \text { Journal, } & 37(6), & \text { 806-817. } \\ \text { https://doi.org/10.1016/j.emj.2019.03.001 } & & & \end{array}$

Gupta, V. K., \& Dutta, D. K. (2018). The rich legacy of Covin and Slevin (1989) and Lumpkin and Dess (1996): A constructive critical analysis of their deep impact on entrepreneurial orientation research. In Foundational research in entrepreneurship studies (pp. 155-177). Palgrave Macmillan, Cham.

Gupta, V. K., Guo, C., Canever, M., Yim, H. R., Sraw, G. K., \& Liu, M. (2012). Institutional environment for entrepreneurship in rapidly emerging major economies: the case of Brazil, China, India, and Korea. International Entrepreneurship and Management Journal, 10(2), 367-384. https://doi.org/10.1007/s11365-012-0221-8

Hair, Joe F., Celsi, M., Money, A., Samouel, P., \& Page, M. (2015). The essentials of business research methods: Third Edition. The Essentials of Business Research Methods: Third Edition, 1-494. https://doi.org/10.4324/9781315716862

Hashem, A. (2018). The effect of strategic decision making tools on rationality of decision making process. International Journal of Business Strategy, 18(1), 11-28. https://doi.org/10.18374/ijbs-18-1.2

Hettich, E., \& Kreutzer, M. (2021). Strategy Formation Across Organizational Boundaries: An Interorganizational Process Model. British Journal of Management, 32(1), 147-199. https://doi.org/10.1111/1467-8551.12473

Horchani, S. C., \& Zouaoui, M. (2019). Entrepreneurial Orientation and Innovation Intensity: A New "Mediated-Moderated" Model Empirical Validation in the Tunisian Context. Journal of Enterprising Culture, 27(03), 309-350. https://doi.org/10.1142/s0218495819500122

Hossain, M. U., \& Asheq, A. A. (2020). Do leadership orientation and proactive personality influence social entrepreneurial intention. International Journal of Management and Enterprise Development, 19(2), 109. https://doi.org/10.1504/ijmed.2020.107396

Hosseini, S., Kees, A., Manderscheid, J., Röglinger, M., \& Rosemann, M. (2017). What does it take to implement open innovation? Towards an integrated capability framework. Business Process Management Journal, 23(1), 87-107. https://doi.org/10.1108/bpmj-03-2016-0066

Houck, A. A., Brock, J. B., \& Chuang, I. L. (2003). Experimental observations of a left-handed material that obeys Snell's law. Physical Review Letters, 90(13), 137401. 
Hoyte, C., Noke, H., Mosey, S., \& Marlow, S. (2019). From venture idea to venture formation: The role of sensemaking, sensegiving and sense receiving. International Small Business Journal: $\quad$ Researching Entrepreneurship, 37(3), 268-288. https://doi.org/10.1177/0266242618818876

Hu, R., Skea, J., \& Hannon, M. J. (2018). Measuring the energy innovation process: An indicator framework and a case study of wind energy in China. Technological Forecasting and Social Change, 127, 227-244.

Hughes, M., Hughes, P., Morgan, R. E., Hodgkinson, I. R., \& Lee, Y. (2020). Strategic entrepreneurship behaviour and the innovation ambidexterity of young technology-based firms in incubators. International Small Business Journal: Researching Entrepreneurship, 39(3), 202-227. https://doi.org/10.1177/0266242620943776

Hughes-Morgan, M., Kolev, K., \& Mcnamara, G. (2018). A meta-analytic review of competitive aggressiveness research. Journal of Business Research, 85, 73-82. https://doi.org/10.1016/j.jbusres.2017.10.053

Hurley, R. F., \& Hult, G. T. M. (1998). Innovation, market orientation, and organizational learning: an integration and empirical examination. Journal of marketing, 62(3), 42-54.

Indriastuti, H. (2019). Entrepreneurial Inattentiveness, Relational Capabilities And Value CoCreation To Enhance Marketing Performance. Humanities \& Social Sciences Reviews, 7(3), 181-188. https://doi.org/10.18510/hssr.2019.7328

Ireland, R. D., \& Webb, J. W. (2006). A multi-theoretic perspective on trust and power in strategic supply chains. Journal of Operations Management, 25(2), 482-497. https://doi.org/10.1016/j.jom.2006.05.004

Jones, P., \& Colwill, A. (2013). Entrepreneurship education: an evaluation of the Young Enterprise Wales initiative. Education + Training, 55(8/9), 911-925. https://doi.org/10.1108/et-042013-0052

Kanter, R. M. (2010). Supercorp: How vanguard companies create innovation, profits, growth, and social good. Profile Books.

Karadağ, H., \& Şahin, F. (2020). Can managers become entrepreneurs? A moderated mediation model of entrepreneurial intention. Canadian Journal of Administrative Sciences / Revue Canadienne Des Sciences de l'Administration, 38(2), 193-208. https://doi.org/10.1002/cjas.1596 
Khan, U. (2021). Effect of Employee Retention on Organizational Performance. Journal of Entrepreneurship, Management, and Innovation , 2(1), 52-66. https://doi.org/10.52633/jemi.v2i1.47

Khan, W. A., Hassan, R. A., Arshad, M. Z., Arshad, M. A., Kashif, U., Aslam, F., \& Wafa, S. A. (2020). The effect of entrepreneurial orientation and organisational culture on firm performance: The mediating role of innovation. International Journal of Innovation, Creativity and Change, 13(3), 652-677.

Kocak, A., Carsrud, A., \& Oflazoglu, S. (2017). Market, entrepreneurial, and technology orientations: impact on innovation and firm performance. Management Decision.

Kottika, E., ÖZsomer, A., Rydén, P., Theodorakis, I. G., Kaminakis, K., Kottikas, K. G., \& Stathakopoulos, V. (2020). We survived this! What managers could learn from SMEs who successfully navigated the Greek economic crisis. Industrial Marketing Management, 88, 352-365. https://doi.org/10.1016/j.indmarman.2020.05.021

Kreiser, P. M., Kuratko, D. F., Covin, J. G., Ireland, R. D., \& Hornsby, J. S. (2019). Corporate entrepreneurship strategy: extending our knowledge boundaries through configuration theory. Small Business Economics, 1-20.

Kuzminski, L., Nadolny, M., \& Wojtaszek, H. (2020). An Innovative Approach to Generational Motivation. EUROPEAN RESEARCH STUDIES JOURNAL, XXIII(Special Issue 1), 679692. https://doi.org/10.35808/ersj/1785

Lawal, S. A. (2020). HR Professional's Perceived Leaders' Emotional Intelligence Impact on Organizational Innovation (Doctoral dissertation, University of Phoenix).

Le Loarne-Lemaire, S., \& Blanco, S. (2012). Innovation management . Pearson Education France.

Lumpkin, G. T., \& Dess, G. G. (1996). Clarifying the Entrepreneurial Orientation Construct and Linking It To Performance. Academy of Management Review, 21(1), 135-172. https://doi.org/10.5465/amr.1996.9602161568

Lumpkin, G., Cogliser, C. C., \& Schneider, D. R. (2009). Understanding and Measuring Autonomy: An Entrepreneurial Orientation Perspective. Entrepreneurship Theory and Practice, 33(1), 47-69. https://doi.org/10.1111/j.1540-6520.2008.00280.x

Marion, T. J., \& Fixson, S. K. (2020). The Transformation of the Innovation Process: How Digital Tools are Changing Work, Collaboration, and Organizations in New Product 
Development*. Journal of Product Innovation Management, 38(1), 192-215. https://doi.org/10.1111/jpim.12547

Marvel, M. R., Wolfe, M. T., \& Kuratko, D. F. (2020). Escaping the knowledge corridor: How founder human capital and founder coachability impacts product innovation in new ventures. Journal of Business Venturing, 35(6), 106060. https://doi.org/10.1016/j.jbusvent.2020.106060

Mazzarol, T., \& Reboud, S. (2005). Customers as predictors of rent returns to innovation in small firms: an exploratory study. International Journal of Entrepreneurship and Innovation Management, 5(5/6), 483. https://doi.org/10.1504/ijeim.2005.007001

Merx-Chermin, M., \& Nijhof, W. J. (2005). Factors influencing knowledge creation and innovation in an organisation. Journal of European Industrial Training.

Miller, D. (2011). Miller (1983) Revisited: A Reflection on EO Research and Some Suggestions for the Future. Entrepreneurship Theory and Practice, 35(5), 873-894. https://doi.org/10.1111/j.1540-6520.2011.00457.x

Nagji, B., \& Tuff, G. (2012). Managing your innovation portfolio. Harvard Business Review, 90(5), 66-74.

Nieto, M. J., Santamaria, L., \& Fernandez, Z. (2015). Understanding the innovation behavior of family firms. Journal of Small Business Management, 53(2), 382-399. DOI: 10.1111/ jsbm. 12075

Okonkwo, O. (2020). Learning and Innovation Through Interfirm Alliances: The Role of Human Resource Development. In The Future of HRD, Volume II (pp. 219-246). Palgrave Macmillan, Cham.

Palmer, C., Niemand, T., Stöckmann, C., Kraus, S., \& Kailer, N. (2019). The interplay of entrepreneurial orientation and psychological traits in explaining firm performance. Journal of Business Research, 94, 183-194. https://doi.org/10.1016/j.jbusres.2017.10.005

Pihlajamaa, M. (2017). Going the extra mile: Managing individual motivation in radical innovation development. Journal of Engineering and Technology Management, 43, 48-66. https://doi.org/10.1016/j.jengtecman.2017.01.003

Randerson, K., \& Fayolle, A. (2010). Management et orientation entrepreneuriale : deux concepts si différents ? Management \& Avenir, 39(9), 124. https://doi.org/10.3917/mav.039.0124 
Rauch, A., Wiklund, J., Lumpkin, G., \& Frese, M. (2009). Entrepreneurial Orientation and Business Performance: An Assessment of past Research and Suggestions for the Future. Entrepreneurship Theory and Practice, 33(3), 761-787. https://doi.org/10.1111/j.15406520.2009.00308.x

Ribeiro-Soriano, D. E., McDowell, W., \& Kraus, S. (2019). Special issue on: innovation and knowledge-based economy for entrepreneurship and regional development. Entrepreneurship \& Regional Development, 32(7-8), 654-656. https://doi.org/10.1080/08985626.2019.1597423

Rondi, E., De Massis, A., \& Kotlar, J. (2019). Unlocking innovation potential: A typology of family business innovation postures and the critical role of the family system. Journal of Family Business Strategy, 10(4), 100236.

Sanyal, S., Hisam, M. W., \& Baawain, A. M. S. (2020). Entrepreneurial Orientation, Network Competence and Human Capital: The Internationalization of SMEs in Oman. The Journal of Asian Finance, Economics and Business, 7(8), 473-483. https://doi.org/10.13106/jafeb.2020.vol7.no8.473

Schumpeter, J. A., \& Nichol, A. J. (1934). Robinson's economics of imperfect competition. Journal of political economy, 42(2), 249-259.

Sebora, T. C., \& Theerapatvong, T. (2010). Corporate entrepreneurship: A test of external and internal influences on managers' idea generation, risk taking, and proactiveness. International Entrepreneurship and Management Journal, 6(3), 331-350.

Shanker, R., Bhanugopan, R., van der Heijden, B. I., \& Farrell, M. (2017). Organizational climate for innovation and organizational performance: The mediating effect of innovative work behavior. Journal of Vocational Behavior, 100, 67-77. https://doi.org/10.1016/j.jvb.2017.02.004

Sheng, M. L., \& Chien, I. (2016). Rethinking organizational learning orientation on radical and incremental innovation in high-tech firms. Journal of Business Research, 69(6), 23022308 .

Shimizu, K. K. (2012). Risks of Corporate Entrepreneurship: Autonomy and Agency Issues. Organization Science, 23(1), 194-206. https://doi.org/10.1287/orsc.1110.0645

Stambaugh, J., Lumpkin, G. T., Mitchell, R. K., Brigham, K., \& Cogliser, C. (2020). Competitive aggressiveness, community banking and performance. Journal of Strategy and Management, 13(2), 221-240. https://doi.org/10.1108/jsma-03-2019-0033 
Stevenson, H. H., \& Jarillo, J. C. (2007). A paradigm of entrepreneurship: Entrepreneurial management. In Entrepreneurship (pp. 155-170). Springer, Berlin, Heidelberg.

Subramaniam, M., \& Youndt, M. A. (2005). The influence of intellectual capital on the types of innovative capabilities. Academy of Management journal, 48(3), 450-463.

Sumo, R., van der Valk, W., van Weele, A., \& Bode, C. (2016). Fostering incremental and radical innovation through performance-based contracting in buyer-supplier relationships. International Journal of Operations \& Production Management.

Teixeira, Rda (2010). Innovation management primer. Brasília: CNI, SEBRAE .

Tidd, J. (2006). A review of innovation models. Imperial College London, 16.

Tonnessen, T. (2005). Continuous innovation through company wide employee participation. The TQM magazine.

Utami, C. W., Tambunan, D., \& Padmalia, M. (2021). Analysis of Innovation, Proactive, and Risk Taking as Presentations of Entrepreneurial Orientation towards Business Success of Second and Third Generation Family Business in Indonesia. Jurnal Entrepreneur Dan Entrepreneurship, 10(1). https://doi.org/10.37715/jee.v10i1.1553

Vasconcellos, L. H. R., \& Marx, R. (2011). Understanding how innovation takes place in service companies-an exploratory study of companies in Brazil. Gestão \& Produção, 18(3), 443460.

Vasconcellos, LHR, \& Marx, R. (2011). How do service innovations occur? An exploratory study of companies in Brazil. Management \& Production , 18 , 443-460.

Walter, A., Auer, M., \& Ritter, T. (2006). The impact of network capabilities and entrepreneurial orientation on university spin-off performance. Journal of business venturing, 21(4), 541567.

Wang, C. L., \& Ahmed, P. K. (2004). The development and validation of the organizational innovativeness construct using confirmatory factor analysis. European journal of innovation management.

Wang, X. H., Fang, Y., Qureshi, I., \& Janssen, O. (2015). Understanding employee innovative behavior: Integrating the social network and leader-member exchange perspectives. Journal of organizational behavior, 36(3), 403-420. 
Wold, H. (1977). On the transition from pattern cognition to model building. In Mathematical Economics and Game Theory (536-549). Springer, Berlin, Heidelberg.

Yi, R., Wang, H., Lyu, B., \& Xia, Q. (2021). Does venture capital help to promote open innovation practice? Evidence from China. European Journal of Innovation Management, aheadof(ahead-of-print). https://doi.org/10.1108/ejim-03-2021-0161

Yu, T., \& Cannella Jr, A. A. (2007). Rivalry between multinational enterprises: An event history approach. Academy of Management Journal, 50(3), 665-686.

Yu, X., \& Si, S. (2012). Innovation, internationalization and entrepreneurship: A new venture research perspective. Innovation, 14(4), 524-539.

Zahra, S., \& Dess, G. G. (2001). Entrepreneurship as a field of research: Encouraging dialogue and debate. Academy of management Review, 26(1), 8-10.

Zhang, J. A., Edgar, F., Geare, A., \& O'Kane, C. (2016). The interactive effects of entrepreneurial orientation and capability-based HRM on firm performance: The mediating role of innovation ambidexterity. Industrial Marketing Management, 59, 131-143.

Zhang, W., Xu, F., \& Sun, B. (2020). Openness to experience, job characteristics, and employee creativity: An interactionist perspective. Social Behavior and Personality: An International Journal, 48(4), 1-12. https://doi.org/10.2224/sbp.9047

Zhao, X., Tan, G., \& Wong, C. H. (2020). The Impact of Self-Efficacy, Growth Mindset, Empowerment and Training on Employees' Innovation Capability: A Conceptual Framework. INTI JOURNAL, 2020(40). 